BMC

Research Notes
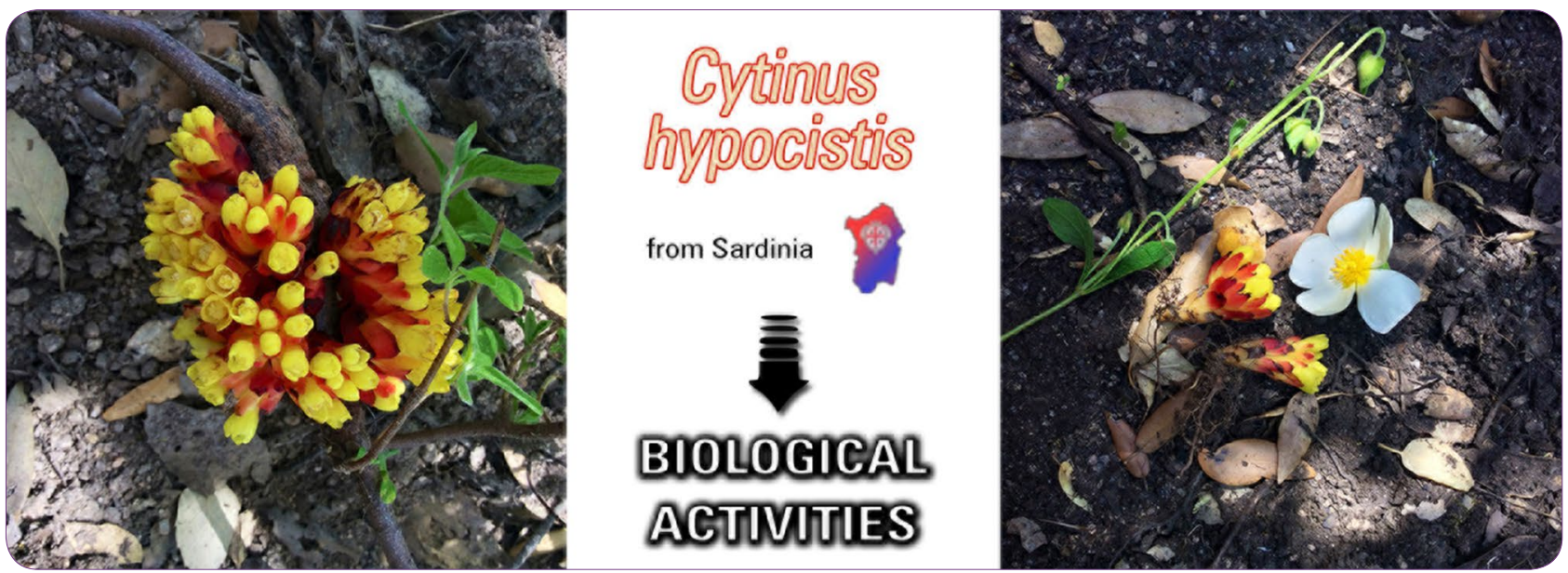

\title{
Antimicrobial, antioxidant and anti-tyrosinase properties of extracts of the Mediterranean parasitic plant Cytinus hypocistis
}

Zucca et al. 


\title{
Antimicrobial, antioxidant and anti-tyrosinase properties of extracts of the Mediterranean parasitic plant Cytinus hypocistis
}

Paolo Zucca ${ }^{1} 2^{*}$, Manuela Pintus ${ }^{1}$, Giorgia Manzo ${ }^{1}$, Mariella Nieddu ${ }^{1}$, Daniela Steri ${ }^{1}$ and Andrea C. Rinaldi ${ }^{1}$

\begin{abstract}
Background: Cytinus is an endophytic parasitic plant occurring in South Africa, Madagascar, and in the Mediterranean region. We have extracted the inflorescences (the only visible part of the plant, emerging from the host roots at the time of blossom) of Cytinus hypocistis collected in Sardinia, Italy, and explored the antimicrobial, antioxidant, antityrosinase, and cytotoxic activities of the extracts.

Methods: Extracts from C. hypocistis were prepared using increasing polarity solvents: cyclohexane, ethanol, and water. Phenolic composition were determined through spectrophotometric assays, and antioxidant activity with both electron-transfer and hydrogen-atom assays. Nine different bacterial strains, including clinical isolate methicillinresistant Staphylococcus aureus, were used in agar diffusion method. Cytotoxicity was tested using against the B16F10 melanoma cell line.

Results: While cyclohexane extracts where biologically inactive, ethanolic and aqueous extracts displayed an intriguing activity against several Gram-positive bacterial strains, including methicillin-resistant $S$. aureus, and against the Gram-negative Acinetobacter baumanii. Compared to the conventional antibiotics like cloxacillin, ampicillin, and oxytetracycline, C. hypocistis extracts were less active in absolute terms, but displayed a wider spectrum (notably, cloxacillin and ampicillin were inactive against methicillin-resistant $S$. aureus). The ethanolic extract of C. hypocistis was found to be particularly rich in polyphenols, in most part hydrolysable tannins. The antioxidant activity of extracts, tested with several methodologies, resulted to be particularly high in the case of ethanolic extracts, in accordance with the composition in phenolics. In detail, ethanol extracts presented about a twofold higher activity than the water sample when tested through the oxygen radical absorbance capacity-pyrogallol red (ORAC-PYR) assay. Cytotoxicity analysis against the B16F10 melanoma cell line showed that both extracts have not significant cytotoxic effect, even at the highest dose $(1000 \mu \mathrm{g} / \mathrm{mL})$. Tests showed that ethanolic extracts also had the greatest tyrosinase inhibition activity, indicating that C. hypocistis-derived substances could find application in food formulations as anti-browning agents.
\end{abstract}

Conclusions: Overall, these results point to the need of further studies on C. hypocistis extracts, aimed at isolating and fully characterizing its biologically active compounds.

Keywords: Cytinus, Cynomorium, Plant extracts, Parasitic plants, Antimicrobial, Antioxidant, Anti-tyrosinase

\section{Background}

Plants host a trove of active substances, and are the basis of both ancient folk remedies and modern pharmacopeia

\footnotetext{
*Correspondence: pzucca@unica.it; paolo.zucca@consorziouno.it ${ }^{1}$ Department of Biomedical Sciences, University of Cagliari, Cittadella Universitaria, Complesso Universitario, SP Monserrato-Sestu Km 0.700, 09042 Monserrato, CA, Italy

Full list of author information is available at the end of the article
}

$[1,2]$. Even among the otherwise well studied European flora, the chemical/biochemical grounds of many traditional healthcare practices remains obscure, and many have called for a renaissance of ethnobiological studiesincluding in this term not only local traditional knowledge regarding medicine sources, but also the environment and wild food-in this part of the Old World [2,3]. 
Cytinus is a genus composed of 8 recognized species (plus several others under study) of nonchlorophyllic plants [4], that parasitize roots of Cistus and Halimium, two genera of shrub plants in the family Cistaceae. Members of Cytinus are rootless, stemless and leafless; flowers are the only visible part, and just during the reproductive period, when they emerge from host tissues. The genus belongs to family Cytinaceae, together with Bdallophyton and Bdallophytum, and occurs in the Mediterranean region, in South Africa and in Madagascar. The reproductive and trophic biology of Cytinus is intriguing. Flowers of the Mediterranean C. hypocistis (L.) L. (Fig. 1a, b) are visited by ants [5], while in South Africa C. sanguineus is pollinated by sunbirds [6] and mammalian pollination has been demonstrated for C. visseri [7]. In this latter case, rodents and elephant shrews seem to be attracted by two aliphatic ketones that dominate the scent of parasite's flowers [7]. A novel trophic interaction involving $C$. hypocistis, Cistaceae host species, and mycorrhizal fungi, with mycorrhizae being associated with both the hosts and the parasites, was recently described [8]. If confirmed [9, 10], this would represent a very rare, if not unique, case of a tripartite association involving an endophytic parasitic plant, its host, and mycorrhizae in natural conditions [11].

In traditional medicine, a decoction of $C$. hypocistis has been used in the treatment of dysentery and for its astringent qualities; other reported uses include the treatment of tumors of the throat and of eye inflammations, and as a emmenagogue [12,13]. The young plant can be cooked as an asparagus substitute, flowers sucked as sweets, and the species is quoted as famine food in Portugal [14-16]. In Turkey, the plant was used to produce a glue [17]. In Sardinia, a recent ethnobotanical survey conducted in a territory situated in the south-central part of the island found that the Cytinus juice has been used in popular medicine as an astringent, tonic, and haemostatic substance [18].

Despite this wealth of traditional uses, the chemical composition of Cytinus is largely unknown, and active substances not identified. To help bridging this gap, and to explore alternative potential medicinal, cosmetic and/ or nutraceutical uses of these plants, we here report the antimicrobial, antioxidant, anti-tyrosinase, and cytotoxic activities of extracts of C. hypocistis collected in Sardinia, Italy, at the core of the Mediterranean center of diversification of the genus. To the best of our knowledge, this is the first report of a screening of antibacterial activities for C. hypocistis, while only antimalarial and antitumoral activities have been reported $[19,20]$.

\section{Methods}

\section{Chemicals and instrumentation}

All reagents were of the best commercial grade available and used without further purification. Ethanol,
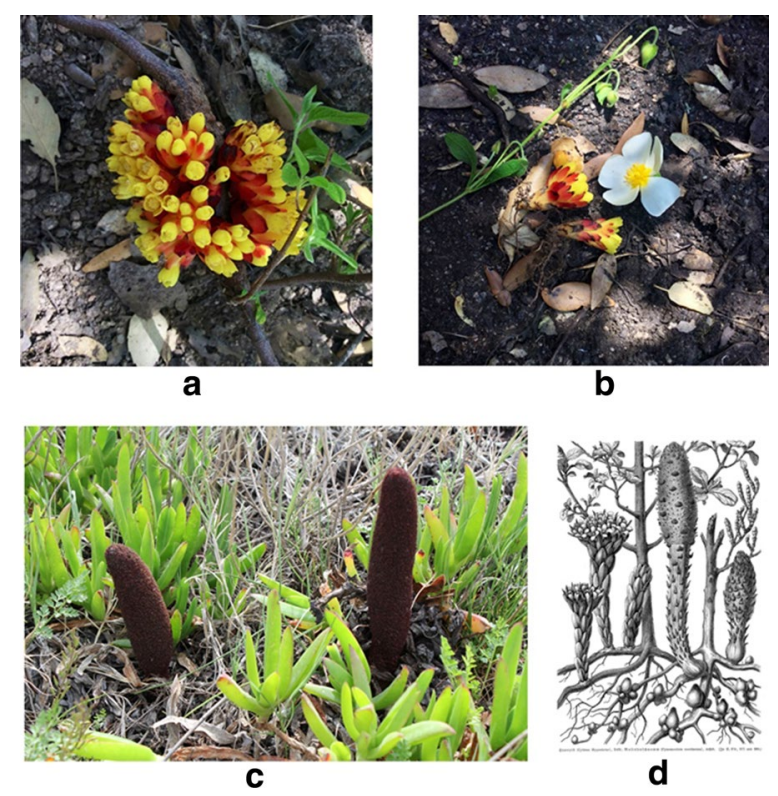

Fig. 1 a Growth habit of Cytinus hypocistis growing on Cistus salvifolius, showing a clump of multiple inflorescences arising from a single parasite; b C. hypocistis inflorescences, side view; c Cynomorium coccineum, the Maltese mushroom, growing in a coastal area of south-western Sardinia, Italy; $\mathbf{d}$ a classic portrait of C. hypocistis and C. coccineum, depicted in the same plate (from [42])

cyclohexane and dimethyl sulfoxide were analytical grade solvents obtained from Sigma-Aldrich, Fluka (Milan, Italy). Ultrapure water $(18 \mathrm{~m} \Omega)$ was obtained with a Milli-Q Advantage A10 System apparatus (Millipore, Milan, Italy). Spectrophotometric measurements were carried out with an UltroSpec 2100pro (Amersham Bioscience, Milan, Italy).

\section{Plant materials}

Fresh inflorescences of Cytinus hypocistis were collected under host plant, Cistus salvifolius, in the vast forested area that extends between Capoterra and Santadi, about $20 \mathrm{~km}$ southwest of Cagliari (Sardinia, Italy), on May 2014. Vouchers are kept in the collection of the Department of Biomedical Sciences at the University of Cagliari, with the accession number ACR-14/5/2014. Specimens were transferred to the laboratory within $1 \mathrm{~h}$ from harvest and freeze dried immediately. Reference material was deposited in the collection of the Department of Biomedical Sciences, University of Cagliari, Cagliari, Italy.

\section{Preparation of the extracts}

Samples of $1 \mathrm{~g}$ of freeze-dried C. hypocistis were suspended in $5 \mathrm{~mL}$ cyclohexane and left under mechanical agitation for $30 \mathrm{~min}$. The supernatant was collected after centrifugation at $5000 \mathrm{~g}$ for $10 \mathrm{~min}$. The extraction 
procedure was repeated 4 times. The extracts were collected, lyophilized and stored at $4{ }^{\circ} \mathrm{C}$. The solid powder was then dried by rotary evaporator, and the whole procedure was repeated using as solvent ethanol, and lastly water, to obtain three extracts of different polarity.

\section{Antimicrobial activity}

Antibacterial activity of the extracts was determined against four Gram-negative and five Gram-positive reference bacterial strains, respectively: Staphylococcus aureus DSM 1104, methicillin-resistant Staphylococcus aureus (MRSA), Staphylococcus epidermidis DSM 1798, Enterococcus faecalis DSM 2570, Escherichia coli DSM 1103, Enterobacter cloacae DSM 30054T, Pseudomonas aeruginosa DSM 1117, Acinetobacter baumannii DSM 30007T, Klebsiella pneumoniae DSM 681. A turbidity equivalent to a 0.5 McFarland standard was prepared by direct saline suspension of isolated colonies selected from an 24-h agar plate. The disc diffusion method was used to carry out the antimicrobial activities of extracts according to CLSI procedures [21, 22]. Inoculum suspensions of each strain were swabbed on the top of the MHA plate prepared with $25 \mathrm{~mL}$ of Mueller-Hinton agar (MHA), and $0.5 \mathrm{mg}$ of dry extract was added to each disk separately, in addition to the control disk. DMSO was used as negative control. Rifampicin, cloxacillin, ampicillin, and oxytetracycline were used as positive controls.

\section{Phenolics determination}

Soluble phenolics content was determined using a spectrophometric approach: $1 \mathrm{~mL}$ of each sample was treated with $2.5 \mathrm{~mL} \mathrm{Na}_{2} \mathrm{CO}_{3} 2 \% \mathrm{w} / v$. After 1 min incubation at $25{ }^{\circ} \mathrm{C}, 0.25 \mathrm{~mL} 1 \mathrm{~N}$ Folin-Ciocalteu reagent was added. The mixture was incubated at $25^{\circ} \mathrm{C}$ in the dark for $45 \mathrm{~min}$ and absorbance at $760 \mathrm{~nm}$ measured. Gallic acid was used as the standard (linearity range $0.05-0.6 \mathrm{mM}$ ), and the results were calculated as gallic acid equivalents $(\mathrm{mM}$ GAE). Quantification of total flavonoids was performed using a spectrophotometric method [23, 24]. Aliquots of $0.25 \mathrm{~mL}$ of sample were incubated for $5 \mathrm{~min}$ at $25^{\circ} \mathrm{C}$ in the presence of $1.25 \mathrm{~mL} \mathrm{H}_{2} \mathrm{O}$ and $0.075 \mathrm{~mL} \mathrm{NaNO}_{2}(5 \%$ $w / v)$. Then, $0.15 \mathrm{~mL} \mathrm{AlCl}_{3}(10 \% w / v)$ was added. After $6 \mathrm{~min}$, samples were alkalinized using $0.5 \mathrm{~mL}$ of $1 \mathrm{M}$ $\mathrm{NaOH}$ and $0.275 \mathrm{~mL} \mathrm{H}_{2} \mathrm{O}$. Absorbance at $510 \mathrm{~nm}$ was then measured. Catechin was used as the standard (linearity range $0.1-0.6 \mathrm{mM}$ ) and results were expressed as Catechin Equivalent (mM CE), using a standard curve. Total anthocyanin content was determined through spectrophotometric assay, based on differential $\mathrm{pH}$ absorbance [25]. $\mathrm{HCl} / \mathrm{KCl} 0.2 \mathrm{M}$ and sodium acetate $1 \mathrm{M}$ buffers were used to record absorbance at $\mathrm{pH} 1.0$ and 4.5, using both 510 and $700 \mathrm{~nm}$ wavelengths. Molar extinction coefficient of cyanidin 3-O-glucoside $\left(29,300 \mathrm{M}^{-1} \mathrm{~cm}^{-1}\right)$ was then used to calculate total anthocyanin, according to Eq. 1 ( $l=$ optical path).

$[$ total anthocyanin $]=\frac{\left[\left(A_{510}-A_{700}\right)_{\mathrm{pH} 1.0}-\left(A_{510}-A_{700}\right)_{\mathrm{pH} 4.5}\right]}{29,300 \mathrm{M}^{-1} \mathrm{~cm}^{-1} \cdot l}$

\section{Determination of antioxidant capacity}

(a) 1,1-Diphenyl-2-picrylhydrazyl radical (DPPH) scavenging assay was performed incubating $0.3 \mathrm{~mL}$ of sample and $0.7 \mathrm{~mL}$ of DPPH solution $(25 \mathrm{mg} / \mathrm{L}$ in ethanol). Decrease in absorbance at $515 \mathrm{~nm}$ was followed for $30 \mathrm{~min}$ at $25{ }^{\circ} \mathrm{C}$. The percentage of DPPH decoloration $\left(\%_{\mathrm{DEC}}\right)$ was calculated as follows: $\%_{\mathrm{DEC}}=100 \times\left[\left(\mathrm{Abs}_{\text {control }}-\mathrm{Abs}_{\text {sample }}\right) / \mathrm{Abs}_{\text {con- }}\right.$ trol]. Trolox was used for the calibration curve (linearity range 5-50 $\mu \mathrm{M}$ ), and results are expressed as Trolox Equivalents (TE) and as $\mathrm{IC}_{50}[23,26]$.

(b) Ferric reducing antioxidant power (FRAP) was determined at $37{ }^{\circ} \mathrm{C}$. Briefly, $2.5 \mathrm{~mL}$ of $10 \mathrm{mM}$ 2,4,6-tripyridyl-s-triazine (TPTZ) in $40 \mathrm{mM} \mathrm{HCl}$ was incubated with $25 \mathrm{~mL}$ of $0.1 \mathrm{M}$ sodium acetate buffer (pH 3.6) and $2.5 \mathrm{~mL}$ of $20 \mathrm{mM} \mathrm{FeCl}_{3}$. After warming to $37{ }^{\circ} \mathrm{C}, 0.2 \mathrm{~mL}$ of this solution were added to $0.77 \mathrm{~mL} \mathrm{H}_{2} \mathrm{O}$ and $0.03 \mathrm{~mL}$ of sample. After 6 min at $25^{\circ} \mathrm{C}$, reaction mixtures were centrifuged at $8000 \mathrm{~g}$ for $10 \mathrm{~min}$, and absorbance at $593 \mathrm{~nm}$ was measured $[24,26]$. The results were expressed as both Trolox Equivalents (mM TE) and mmol of $\mathrm{Fe}(\mathrm{II})$ per gram of dry material ( $\mathrm{mmol} \mathrm{Fe} / \mathrm{II}$ ).

(c) The trolox equivalent antioxidant capacity (TEAC) assay was performed using 2,2'-azinobis(3-ethylbenzothiazoline 6-sulphonate) (ABTS) cationic radical, obtained by reaction between $7 \mathrm{mmol}$ aqueous $\mathrm{ABTS}$ and $2.45 \mathrm{mmol}$ aqueous $\mathrm{K}_{2} \mathrm{~S}_{2} \mathrm{O}_{8}$ at $25{ }^{\circ} \mathrm{C}$ for $16 \mathrm{~h}$. Dilution with sodium phosphate buffer $75 \mathrm{mM}$ (pH 7.4) was used to reach absorbance $0.70 \pm 0.01$ at $734 \mathrm{~nm}$. Samples of $0.01 \mathrm{~mL}$ were then diluted with $1 \mathrm{~mL}$ of this ABTS radical solution, and absorbance at $734 \mathrm{~nm}$ was measured after $6 \mathrm{~min}$ at $25^{\circ} \mathrm{C}$ [23]. The percentage of ABTS decoloration (\%DEC) was calculated as follows: $\% \mathrm{DEC}=100 \times\left[\left(\mathrm{Abs}_{\text {control }}-\mathrm{Abs}_{\text {sample }}\right) / \mathrm{Abs}_{\text {control }}\right]$. The results were expressed as Trolox Equivalents ( $\mathrm{mM} \mathrm{TE} / \mathrm{g}$, linearity range $0.1-0.8 \mathrm{mM})$, and as $\mathrm{IC}_{50}$.

d) Oxygen radical absorbance capacity-pyrogallol red (ORAC-PYR) assay was performed incubating $0.75 \mathrm{~mL}$ of $6.6 \mathrm{mM}$ pyrogallol red solution in $75 \mathrm{mM}$ potassium phosphate buffer $(\mathrm{pH}$ 7.4) and $0.125 \mathrm{~mL}$ of the sample at $25^{\circ} \mathrm{C}$ for $10 \mathrm{~min}$. Then

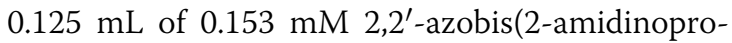
pane) dihydrochloride (APH) solution in $75 \mathrm{mM}$ potassium phosphate buffer ( $\mathrm{pH}$ 7.4) were added, 
following the decrease in absorbance at $540 \mathrm{~nm}$ for $35 \mathrm{~min}$ at $25^{\circ} \mathrm{C}$. The area under the kinetic curve was calculated $\left(\mathrm{AUC}_{\text {net }}\right)$ by subtracting the area of the blank $\left(\mathrm{AUC}_{\text {blank }}\right)$ from the area of the sample $\left(\mathrm{AUC}_{\text {sample }}\right): \mathrm{AUC}_{\text {net }}=\mathrm{AUC}_{\text {sample }}-\mathrm{AUC}_{\text {blank }}[23$, 24]. The results were expressed as Trolox Equivalents ( $\mathrm{mM}$ TE, linearity range $0.1-0.8 \mathrm{mM}$ ).

\section{Tyrosinase inhibition}

Tyrosinase from Agaricus bisporus was purified as already described [27]. Contaminant enzymic activities were carefully checked [28]. Laccase activity was not detectable $(<0.001$ E.U. $/ \mathrm{mL}$, using syringaldazine as the substrate $[29,30])$. Spectrophotometric assay involving the adduct between 4-tert-butyl-1,2-benzoquinone (TBBQ) and 4-amino- $N, N$-diethylaniline (ADA) was performed [31], in order to avoid colorimetric interference by colored extracts (common tyrosinase substrates yield red-yellow products, quite similar to the color of the extracts). The assay mixture contained $50 \mathrm{mM}$ sodium phosphate buffer $\mathrm{pH}$ 7.0, $5 \mathrm{mM}$ 4-tert-butylcatechol (TBC), $0.75 \mathrm{mM}$ ADA and 2 E.U. of enzyme in a final volume of $1 \mathrm{~mL}$. The increase in absorbance at $625 \mathrm{~nm}$ $\left(\varepsilon_{625}=11,120 \mathrm{M}^{-1} \mathrm{~cm}^{-1}\right.$ [32]) was followed. 1 Tyrosinase E.U. was defined as the amount of enzyme capable of producing $1 \mu \mathrm{mol}$ of the adduct between TBBQ and ADA per minute at $\mathrm{pH} 7$ and $25^{\circ} \mathrm{C}$. The amount of inhibition by the test samples was expressed as the concentration necessary to achieve $50 \%$ inhibition $\left(\mathrm{IC}_{50}\right)$.

\section{Cell line and culture conditions}

The B16F10 mouse melanoma cell line, (ICLC ATL 99010) was purchased from the National Institute for Cancer Research c/o CBA (Genoa, Italy). Subcultures of cell line were grown in $75-\mathrm{cm}^{2}$ culture flask in DMEM medium supplemented with $10 \%$ fetal bovine serum (FBS), $2 \mathrm{mM}$ L-Glutamine, $1 \%$ non-essential amino acids, $1 \mathrm{mM}$ Na-pyruvate, penicillin $(100 \mathrm{U} / \mathrm{mL})$ and streptomycin $(100 \mu \mathrm{g} / \mathrm{mL})$ at $37{ }^{\circ} \mathrm{C}$ in $5 \% \mathrm{CO}_{2}$.

\section{MTT assay for cell viability}

The cytotoxic effect of $C$. hypocistis extracts was evaluated in B16F10 melanoma cells using the 3-(4,5-dimethylthiazol-2-yl)-2,5-diphenyltetrazolium bromide (MTT) assay, based on the cleavage of the tetrazolium salt by mitochondrial dehydrogenases in viable cells [33, 34]. MTT is a yellow water-soluble tetrazolium salt. Metabolically active cells are able to convert the dye to waterinsoluble dark blue formazan by reductive cleavage of the tetrazolium ring. In brief, $3 \times 10^{3}$ cells $/ \mathrm{mL}$ in $100 \mu \mathrm{L}$ of medium were seeded into a 96-well plate and incubated at $37{ }^{\circ} \mathrm{C}$. After $48 \mathrm{~h}$ incubation, various concentrations ranging from 25 to $1000 \mu \mathrm{g} / \mathrm{mL}$ of aqueous and ethanolic extracts, were added to cultures and incubated for additional $24 \mathrm{~h}$ at $37{ }^{\circ} \mathrm{C}$. An $8 \mu \mathrm{L}$ portion of MTT solution $\left(5 \mathrm{mg} / \mathrm{mL}\right.$ in $\left.\mathrm{H}_{2} \mathrm{O}\right)$ was then added and left for $4 \mathrm{~h}$ at $37^{\circ} \mathrm{C}$. The cells were lysed with $100 \mu \mathrm{L}$ of DMSO and color development was measured at $570 \mathrm{~nm}$ with an auto microplate reader (Infinite 200, Tecan, Austria). The absorbance was proportional to the number of viable cells.

\section{Statistical analysis}

Grafit 7 (Erithacus Software, London UK) and R 2.5.1 software ( $\mathrm{R}$ Foundation for Statistical Computing, Vienna), were used for statistical analysis. All analyses were performed in triplicate, unless otherwise stated. Data of all experiments are the means and standard deviations of three independent experiments involving triplicate analyses for each sample. Evaluation of the statistical significance of differences was performed using one-way analysis of variation (One-way ANOVA), and Bonferroni post test

\section{Results and discussion}

Despite its numerous applications in traditional medicine $[12,14,17]$, the chemical composition of C. hypocistis is still almost completely unknown. To give some insight into this, we firstly fractionated the freeze dried plant using three sequential extraction steps with increasingly polar solvents: cyclohexane, ethanol, and water. The hydrophobic portion of the plant was minimal (cyclohexane in fact extracted about $0.5 \mathrm{~g}$ per $100 \mathrm{~g}$ dried plant), whereas ethanol and water allowed significant recovery of material (28.1 and $16.3 \%$, respectively).

The full pattern of antimicrobial activities displayed by C. hypocistis extract is reported in Table 1. In our hands, cyclohexane extracts were not active. On the contrary, both ethanolic and aqueous extracts displayed an intriguing activity against all the tested Gram-positive bacterial strains. In fact, in all cases inhibition zones were higher than $10 \mathrm{~mm}$ when only $0.5 \mathrm{mg}$ of extracts were deposited in each disc. Alves and coworkers [35] suggest that inhibition zones $<9 \mathrm{~mm}$ correspond to inactive samples, whereas larger inhibition zones correspond to active antimicrobial samples. Particularly, the activity against the clinical isolate methicillin-resistant $S$. aureus is of remarkable interest.

Compared to the conventional antibiotics cloxacillin and ampicillin, tested under identical conditions, $C$. hypocistis extracts were less active in absolute terms, but displayed a wider spectrum. Significantly, both cloxacillin and ampicillin were inactive against MRSA S. aureus. In addition, ethanolic and aqueous extracts were also active against the Gram-negative A. baumanii DSM 30007 strain, and the level of potency was comparable to that of oxytetracycline (Table 1). No other data are present in the 
Table 1 Antibacterial activity of Cytinus hypocistis extracts using disc diffusion method (zone of inhibition in mm)

\begin{tabular}{|c|c|c|c|c|}
\hline & $\begin{array}{l}\text { Cyclohexane extract } \\
0.5 \mathrm{mg} / \text { disc }(\mathrm{mm})\end{array}$ & $\begin{array}{l}\text { Ethanolic extract } \\
0.5 \mathrm{mg} / \text { disc }(\mathrm{mm})\end{array}$ & $\begin{array}{l}\text { Water extract } \\
0.5 \mathrm{mg} / \text { disc }(\mathrm{mm})\end{array}$ & $\begin{array}{l}\text { Antibiotic } \\
\text { control }\end{array}$ \\
\hline \multicolumn{5}{|l|}{ Gram negative } \\
\hline $\begin{array}{l}\text { Escherichia coli } \\
\text { DSM } 1103\end{array}$ & $0.0 \pm 0.0$ & $0.0 \pm 0.0$ & $0.0 \pm 0.0$ & Amp $18.7 \pm 0.6$ \\
\hline $\begin{array}{l}\text { Enterobacter cloacae } \\
\text { DSM } 30054\end{array}$ & $0.0 \pm 0.0$ & $0.0 \pm 0.0$ & $0.0 \pm 0.0$ & Oxy $19.7 \pm 1.2$ \\
\hline $\begin{array}{l}\text { Pseudomonas aeruginosa } \\
\text { DSM } 1117\end{array}$ & $0.0 \pm 0.0$ & $0.0 \pm 0.0$ & $0.0 \pm 0.0$ & Rif $11.3 \pm 0.6$ \\
\hline $\begin{array}{l}\text { Acinetobacter baumanii } \\
\text { DSM } 30007\end{array}$ & $0.0 \pm 0.0$ & $10.5 \pm 3.5$ & $10 \pm 2.8$ & Oxy $15.3 \pm 2.3$ \\
\hline $\begin{array}{l}\text { Klebsiella pneumoniae } \\
\text { DSM } 681\end{array}$ & $0.0 \pm 0.0$ & $0.0 \pm 0.0$ & $0.0 \pm 0.0$ & Amp $8.7 \pm 0.6$ \\
\hline \multicolumn{5}{|l|}{ Gram positive } \\
\hline $\begin{array}{l}\text { Staphylococcus aureus } \\
\text { DSM } 1104\end{array}$ & $0.0 \pm 0.0$ & $13.0 \pm 0.0$ & $13.5 \pm 2.1$ & Clox $30.5 \pm 0.7$ \\
\hline $\begin{array}{l}\text { Staphylococcus aureus } \\
\text { MRSA }\end{array}$ & $0.0 \pm 0.0$ & $11.5 \pm 0.7$ & $11.0 \pm 1.4$ & Clox $0.0 \pm 0.0$ \\
\hline $\begin{array}{l}\text { Staphylococcus epidermidis } \\
\text { DSM } 1798\end{array}$ & $0.0 \pm 0.0$ & $18 \pm 4.2$ & $18.0 \pm 2.8$ & Clox $31.5 \pm 0.7$ \\
\hline $\begin{array}{l}\text { Enterococcus faecalis } \\
\text { DSM } 2570\end{array}$ & $0.0 \pm 0.0$ & $10 \pm 2.8$ & $9.0 \pm 2.8$ & Amp $23.0 \pm 0.0$ \\
\hline
\end{tabular}

Rifampicin, cloxacillin, ampicillin, and oxytetracicline, were used as reference antibiotic controls

Rif rifampicin (30 $\mu \mathrm{g} / \mathrm{disc})$, Clox cloxacillin (5 $\mu \mathrm{g} / \mathrm{disc})$, Amp ampicillin (10 $\mu \mathrm{g} / \mathrm{disc})$, Oxy oxytetracycline $(10 \mu \mathrm{g} / \mathrm{disc})$

literature on the antimicrobial properties of Cytinus, with the only exception of a report on the activity of methanol extracts on two strains of Plasmodium falciparum, with antimalarial activity potentially attributed to hydrolysable tannins [19]. Given the well-known antimicrobial properties of hydrolysable tannins [36], and the composition of Cytinus (see below), it is likely that these secondary metabolites might be responsible for the remarkable antibacterial activity of Cytinus extracts, as recorded in this study.

To roughly elucidate the composition of the extracts from $C$. hypocistis, the polyphenolic component of the samples was quantified using the Folin-Ciocalteu method for total phenolics, $\mathrm{NaNO}_{2} / \mathrm{AlCl}_{3}$-based assay for the determination of total flavonoids, and the differential $\mathrm{pH}$ absorbance method for total anthocyanins. Results are summarized in Table 2. The ethanolic extract was the richest fraction with almost twice the phenolics than the water analogue, whereas the cyclohexane extract was by far the poorest. In all three extracts, flavonoids accounted for only a small part of total phenolics, whereas no anthocyanins were detected. This is in accordance with a previous study of the chemical composition of Cytinus [20]. In this paper, Cytinus samples collected in Greece were analyzed and hydrolysable tannins (mainly gallic acid derivatives) were identified as the main component [20]. Another hydrolysable tannin of the ellagitannin class, named isoterchebin, was found to be responsible for the yellow pigment of C. hypocistis [37].

Cytinus hypocistis extracts were then evaluated for their antioxidant activity using three different electrontransfer-based (ET) methods. Since the ET methods are able to detect only reducing capacity, and not complete antioxidant activity [24, 26], a spectrophotometric HAT method (ORAC-PYR) was also included in the study. In accordance with this observation, the results displayed in Table 2 show that ORAC-PYR gave in all cases the highest antioxidant capacity for all the tested samples, as already demonstrated for other plant samples [23, 33]. In strict agreement with the phenolics composition, the cyclohexane extract showed the poorest antioxidant activity, whereas the alcoholic extract presented about a twofold higher ORAC-PYR activity than the water sample. To the best of our knowledge, this is the first report about polyphenolic composition and antioxidant activity for $C$. hypocistis, and no comparison is possible among the same genus or even family. As reported above, the few available studies describe hydrolysable tannins as important constituents of Cytinus samples [20, 37]. We rather suggest the comparison with Cynomorium coccineum (Cynomoriaceae, Fig. 1c, d), another parasitic and non-photosynthetic plant occurring in the same geographic area, which has been already fully analyzed about chemical composition and antioxidant capacity [23, 33, 
Table 2 Total antioxidant capacity of extracts from Cytinus hypocistis

\begin{tabular}{llll}
\hline Assay & Cyclohexane extract & Ethanolic extract & Water extract \\
\hline ORAC-PYR $(\mathrm{mTE} / \mathrm{g})$ & $1.5 \pm 0.4$ & $28.1 \pm 2.5$ & $13.7 \pm 1.3$ \\
DPPH $(\mathrm{mTE} / \mathrm{g})$ & $0.20 \pm 0.03$ & $2.25 \pm 0.07$ & $1.01 \pm 0.07$ \\
$\mathrm{DPPH}\left(\mathrm{IC}_{50} \mathrm{\mu g} / \mathrm{mL}\right)$ & $95.0 \pm 0.2$ & $24.2 \pm 0.5$ & $24.5 \pm 0.8$ \\
TEAC $(\mathrm{mTE} / \mathrm{g})$ & $0.64 \pm 0.09$ & $7.22 \pm 0.08$ & $5.32 \pm 0.02$ \\
TEAC $\left(\mathrm{IC} \mathrm{C}_{50} \mathrm{mg} / \mathrm{mL}\right)$ & $0.800 \pm 0.132$ & $0.071 \pm 0.009$ & $0.089 \pm 0.002$ \\
FRAP $(\mathrm{mTE} / \mathrm{g})$ & $0.27 \pm 0.01$ & $6.70 \pm 0.03$ & $6.69 \pm 0.09$ \\
FRAP $(\mathrm{mmol}$ Fe"/g) & $1.20 \pm 0.01$ & $22.5 \pm 0.1$ & $20.9 \pm 0.1$ \\
Total phenolics (mGAE/g) & $1.22 \pm 0.12$ & $7.82 \pm 0.01$ & $4.32 \pm 0.05$ \\
Total flavonoids (mCE/g) & $0.18 \pm 0.01$ & $0.63 \pm 0.01$ & $0.69 \pm 0.02$ \\
Total anthocyanin (mg cyanidin 3-O-glucoside/g) & n.d. & n.d. & n.d. \\
\hline
\end{tabular}

Data are the means of at least three independent determinations \pm SD

n.d. not detectable

38]. C. coccineum antioxidant capacity of both water and alcoholic extracts showed quite similar values for both samples (ORAC-PYR was respectively 1.18 and $0.91 \mathrm{mM}$ $\mathrm{TE} / \mathrm{g}$ ) [23]. The C. hypocistis alcoholic extract was on the contrary significantly more active than the water extract, suggesting a different chemical composition compared to C. coccineum, where gallic acid and cyanidin 3-O-glucoside were the main constituents [23]. It should be noted that in C. hypocistis extracts no cyanidins or anthocyanins were detected using the described spectrophotometric assay [25].

Besides, C. hypocistis extracts showed a greater antioxidant activity than $C$. coccineum samples; antioxidant activity of ethanolic extract was almost 20 -fold higher, taking into account ORAC-PYR assay [23]. However, in the cited paper, a different extraction procedure was performed. When the same protocol used in the current study was applied, C. coccineum water extract gave $6.8 \mathrm{mM}$ TE/g ORAC-PYR activity (Zucca et al., in preparation), being in any case significantly lower than both C. hypocistis alcoholic and water extracts. According to the obtained data, C. hypocistis can be assessed as a valuable source of antioxidant chemicals, even for food formulations.

Tyrosinase (or polyphenoloxidase PPO) is a wellknown enzyme involved in melanogenesis and food browning. Accordingly, the development of new inhibitors of this enzymic activity is a very productive field of research [39-41]. To avoid any interference with the tyrosinase inhibition tests, both mono- and di-phenolase activity was ruled out in the C. hypocistis extracts, using common activity assays already reported [27, 31]. All the extracts were able to inhibit PPO activity, albeit at very different extents. Particularly, the cyclohexane extract was about one order of magnitude less effective $\left(\mathrm{IC}_{50} 263 \mu \mathrm{g}\right)$ than water and ethanolic extracts. The latter presented the lowest $\mathrm{IC}_{50}$ $(4.01 \mu \mathrm{g})$, being even lower than C. coccineum water extract $(15.6 \mu \mathrm{g})$ (Zucca et al., in preparation). These data are quite promising as well in the perspective of C. hypocistis application in food formulations as an anti-browning agent.

Cytinus hypocistis extracts have been also evaluated for their ability to affect the viability of tumoral cell lines. In accordance, the relationship between concentration of extracts and cell viability of B16F10 melanoma cells was investigated by the MTT assay. B16-F10 cells were treated with aqueous and ethanolic extracts of $C$. hypocistis at concentrations ranging from 25 to $1000 \mu \mathrm{g} / \mathrm{mL}$ for $24 \mathrm{~h}$ at $37^{\circ} \mathrm{C}$. We have chosen such a range of concentrations on the basis of similar experiments performed with water extracts and fixed oil from C. coccineum $[33,38]$. In C. coccineum the same concentrations showed significant toxicity against B16F10 cells. The results of the MTT cell viability assay showed that treatment with both the extracts, in this case, did not have a significant cytotoxic effect even at the highest dose $(1000 \mu \mathrm{g} / \mathrm{mL})$ on this tumoral cell line (Fig. 2). Our data are at variance with that reported by Magiatis and coworkers [20], who found that the methanolic extracts Greek Cytinus exhibited cytotoxic activity against several cancer cell lines, although B16F10 melanoma cells were not tested. The authors attributed this cytotoxic activity to hydrolysable tannins, without any obvious dependence on their molecular weights [20]. Future experiments will be needed to investigate the effect on different (not tumor) cell lines and to validate these results for possible pharmaceutical (i.e. antimicrobial), nutraceutical, and/or cosmetic use. 


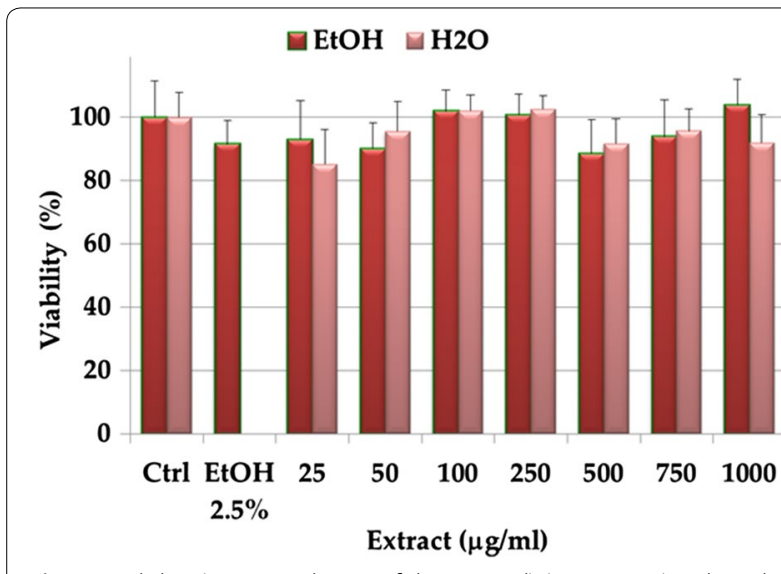

Fig. 2 Viability (expressed as \% of the control) (MTT assay) induced by $24 \mathrm{~h}$ incubation with $\mathrm{C}$. hypocistis aqueous and ethanolic extracts $(25-1000 \mu \mathrm{g} / \mathrm{mL})$ in melanoma B16F10 cells. Data are the means \pm standard deviations of three independent experiments involving triplicate analyses for each sample

Table 3 Summary of the biological activities detected in this paper for $C$. hypocistis extracts

\begin{tabular}{llll}
\hline & $\begin{array}{l}\text { Cyclohexane } \\
\text { extract }\end{array}$ & $\begin{array}{l}\text { Ethanolic } \\
\text { extract }\end{array}$ & $\begin{array}{l}\text { Water } \\
\text { extract }\end{array}$ \\
\hline $\begin{array}{l}\text { Amount (g/100 g of dried plant } 0.5 \% \\
\text { material) }\end{array}$ & $28.1 \%$ & $16.3 \%$ \\
$\begin{array}{l}\text { Antioxidant activity } \\
\text { Antibacterial activity (Gram- }\end{array}$ & - & +++ & ++ \\
$\quad \begin{array}{l}\text { positive) } \\
\text { Antibacterial activity (Gram- } \\
\text { negative) }\end{array}$ & - & ++ & ++ \\
$\begin{array}{l}\text { Anti-tyrosinase activity } \\
\begin{array}{l}\text { Cytotoxicity against B16F10 } \\
\text { melanoma cells }\end{array}\end{array}$ & - & \pm & \pm \\
\hline
\end{tabular}

\section{Conclusions}

On the whole, Cytinus is a plant endowed with intriguing antibacterial, antioxidant and anti-tyrosinase properties, as encompassed in Table 3. The reported data are promising in the perspective of the confirmation of the ethnobotanical application of the plants. Further efforts will be however devoted in the near future in order to isolate and fully characterize biologically active compound(s).

\section{Abbreviations}

DPPH: 1,1-diphenyl-2-picrylhydrazyl; TEAC: trolox equivalent antioxidant capacity; FRAP: ferric reducing antioxidant power; APH: 2,2'-Azo-bis(2-amidopropane)dihydrochloride; ORAC: oxygen radical absorbance capacity; GAE: gallic acid equivalents; TE: trolox equivalents; MTT: 3-(4,5-dimethylthiazol-2-yl)2,5-diphenyltetrazolium bromide.

\section{Authors' contributions}

PZ performed the main part of the experiments and drafted the manuscript. MP performed antimicrobial assays and helped the analysis of the data. GM performed antioxidant assays and helped the analysis of the data. MN performed cytoxicity analysis and helped in the drafting of the manuscript. DS performed anti-tyrosinase, and phenolic composition assays, and helped the analysis of the data. ACR conceived the study, performed the coordination of the study, and worked on the data analysis and interpretation. All authors read and approved the final manuscript.

\section{Author details}

${ }^{1}$ Department of Biomedical Sciences, University of Cagliari, Cittadella Universitaria, Complesso Universitario, SP Monserrato-Sestu Km 0.700, 09042 Monserrato, CA, Italy. ${ }^{2}$ Consorzio UNO, Oristano, Italy.

\section{Acknowledgements}

This work was partially supported by Grants from the Università di Cagliari (Contributo di Ateneo per la Ricerca, C.A.R. 2012-13-14) for PZ, MN, and ACR.

\section{Competing interests}

The authors declare that they have no competing interests.

Received: 8 July 2015 Accepted: 5 October 2015

Published online: 13 October 2015

\section{References}

1. Sanjust E, Mocci G, Zucca P, Rescigno A. Mediterranean shrubs as potential antioxidant sources. Nat Prod Res. 2008;22(8):689-708.

2. Pardo-de-Santayana M, Pieroni A, Puri RK. Ethnobotany in the New Europe: people, health and wild plant resources. New York: Berghahn Books: 2010.

3. Quave CL, Pardo-De-Santayana M, Pieroni A. Medical ethnobotany in Europe: from field ethnography to a more culturally sensitive evidence-based cam? Evid Based Complement Alternat Med. 2012. doi:10.1155/2012/156846.

4. http://www.theplantlist.org/browse/A/Cytinaceae/Cytinus/.

5. De Vega C, Arista M, Ortiz PL, Herrera CM, Talavera S. The ant-pollination system of Cytinus hypocistis (Cytinaceae), a Mediterranean root holoparasite. Ann Bot. 2009;103(7):1065-75.

6. Hobbhahn N, Johnson SD. Sunbird pollination of the dioecious root parasite Cytinus sanguineus (Cytinaceae). S Afr J Bot. 2015;99:138-43.

7. Johnson SD, Burgoyne PM, Harder LD, Dötterl S. Mammal pollinators lured by the scent of a parasitic plant. Proc R Soc Lond (Biol). 2011:278(1716):2303-10.

8. de Vega C, Arista M, Ortiz PL, Talavera S. Anatomical relations among endophytic holoparasitic angiosperms, autotrophic host plants and mycorrhizal fungi: a novel tripartite interaction. Am J Bot. 2010;97(5):730-7.

9. Brundrett MC. Commentary on the de Vega et al. (2010) paper on hyphae in the parasitic plant Cytinus: Mycorrhizal fungi growing within plants are not always mycorrhizal. Am J Bot. 2011;98(4):595-6.

10. de Vega C, Arista M, Ortiz PL, Talavera S. Mycorrhizal fungi and parasitic plants: reply. Am J Bot. 2011;98(4):597-601.

11. Comandini $O$, Contu M, Rinaldi AC. An overview of Cistus ectomycorrhizal fungi. Mycorrhiza. 2006;16(6):381-95.

12. Ashur A, Lev E. New Genizah documents: three fragments on practical medicine in medieval Egypt. Ginzei Qedem. 2013;9:9-35.

13. http://www.ars-grin.gov/cgi-bin/duke/ethnobot.pl?ethnobot taxon=Cytinus\%20hypocistis.

14. Carvalho AM, Morales R. Persistence of wild food and wild medicinal plant knowledge in a Northeastern region of Portugal. Ethnobot New Europe People Health Wild Plant Resour. 2010;14:147-71.

15. Pardo-de-Santayana M, Tardío J, Blanco E, Carvalho AM, Lastra JJ, San Miguel E, Morales R. Traditional knowledge of wild edible plants used in the northwest of the Iberian Peninsula (Spain and Portugal): a comparative study. J Ethnobiol Ethnomed. 2007;3:27.

16. Tardío J, Pardo-De-Santayana M, Morales R. Ethnobotanical review of wild edible plants in Spain. Bot J Linn Soc. 2006;152(1):27-71.

17. Ertuğ F. Wild edible plants of the Bodrum area (Muğla, Turkey). Turk J Bot. 2004;28(1-2):161-74.

18. Loi MC, Frailis L, Maxia A. Medicinal plants commonly used in the Gestury territory (Central-Southern Sardinia). Atti Soc Tosc Sci Nat Mem Ser B. 2002;109:167-76. 
19. Fokialakis N, Kalpoutzakis E, Tekwani BL, Khan SI, Kobaisy M, Skaltsounis $\mathrm{AL}$, Duke SO. Evaluation of the antimalarial and antileishmanial activity of plants from the Greek island of Crete. J Nat Med. 2007;61(1):38-45.

20. Magiatis P, Pratsinis H, Kalpoutzakis E, Konstantinidou A, Davaris $P$, Skaltsounis AL. Hydrolyzable tannins, the active constituents of three Greek Cytinus taxa against several tumor cell lines. Biol Pharm Bull. 2001;24(6):707-9.

21. Institute CaLS. Performance standards for antimicrobial disk susceptibility testing. Approved Standard, 11th edn. In: NCCLS document M02-A11, vol. 32. 2012.

22. Chowdhury M, Kubra K, Ahmed S. Screening of antimicrobial, antioxidant properties and bioactive compounds of some edible mushrooms cultivated in Bangladesh. Ann Clin Microbiol Antimicrob. 2015;14(1):8.

23. Zucca P, Rosa A, Tuberoso CIG, Piras A, Rinaldi AC, Sanjust E, Dessì MA, Rescigno A. Evaluation of antioxidant potential of "Maltese mushroom" (Cynomorium coccineum) by means of multiple chemical and biological assays. Nutrients. 2013;5(1):149-61.

24. Zucca P, Sanjust E, Trogu E, Sollai F, Rescigno A. Evaluation of antioxidant capacity of antioxidant-declared beverages marketed in Italy. Ital J Food Sci. 2010;22(3):313-9.

25. Delazar A, Khodaie L, Afshar J, Nahar L, Sarker S. Isolation and free-radicalscavenging properties of cyanidin 3-O-glycosides from the fruits of Ribes biebersteinii Berl. Acta Pharm. 2010;60(1):1-11.

26. Huang D, Ou B, Prior RL. The chemistry behind antioxidant capacity assays. J Agric Food Chem. 2005;53(6):1841-56.

27. Sollai F, Zucca P, Sanjust E, Steri D, Rescigno A. Umbelliferone and esculetin: inhibitors or substrates for polyphenol oxidases? Biol Pharm Bull. 2008;31(12):2187-93.

28. Rescigno A, Zucca P, Flurkey A, Inlow J, Flurkey WH. Identification and discrimination between some contaminant enzyme activities in commercial preparations of mushroom tyrosinase. Enzyme Microb Technol. 2007;41(5):620-7.

29. Zucca P, Rescigno A, Olianas A, MacCioni S, Sollai FA, Sanjust E. Induction, purification, and characterization of a laccase isozyme from Pleurotus sajor-caju and the potential in decolorization of textile dyes. J Mol Catal B Enzym. 2011;68(2):216-22.

30. Zucca P, Vinci C, Rescigno A, Dumitriu E, Sanjust E. Is the bleaching of phenosafranine by hydrogen peroxide oxidation catalyzed by silicasupported 5,10,15,20-tetrakis-(sulfonatophenyl)porphine-Mn(III) really biomimetic? J Mol Catal A Chem. 2010;321(1-2):27-33.

31. Zucca P, Sanjust E, Loi M, Sollai F, Ballero M, Pintus M, Rescigno A. Isolation and characterization of polyphenol oxidase from Sardinian poisonous and non-poisonous chemotypes of Ferula communis (L.). Phytochemistry. 2013:90:16-24.
32. Asthana S, Zucca P, Vargiu AV, Sanjust E, Ruggerone P, Rescigno A. Structure-activity relationship study of hydroxycoumarins and mushroom tyrosinase. J Agric Food Chem. 2015;63(32):7236-44.

33. Rosa A, Rescigno A, Piras A, Atzeri A, Scano P, Porcedda S, Zucca P, Assunta Dessì M. Chemical composition and effect on intestinal Caco-2 cell viability and lipid profile of fixed oil from Cynomorium coccineum L. Food Chem Toxicol. 2012;50(10):3799-807.

34. Schiller CD, Kainz A, Mynett K, Gescher A. Assessment of viability of hepatocytes in suspension using the MTT assay. Toxicol In Vitro. 1992;6(6):575-8

35. De Almeida Alves TM, Fonseca Silva A, Brandão M, Mesquita Grandi TS, Smânia EDFA, Smânia Jr A, Zani CL. Biological screening of Brazilian medicinal plants. Mem Inst Oswaldo Cruz 2000; 95:367-73.

36. Buzzini P, Arapitsas P, Goretti M, Turchetti B, Pinelli P, leri F, Romani A. Antimicrobial and antiviral activity of hydrolysable tannins. Mini-Rev Med Chem. 2008;8(12):1179-87.

37. Schildknecht H, Herb R, Kunzelmann P. Die Chemie der Schmarotzerblumen, II. Isoterchebin: Struktur des gelben Ellagitannin-Farbstoffes aus Cytinus hypocistis (Rafflesiaceae). Liebigs Ann Chem 1985; 1985(7):1448-56.

38. Rosa A, Nieddu M, Piras A, Atzeri A, Putzu D, Rescigno A. Maltese mushroom (Cynomorium coccineum L.) as source of oil with potential anticancer activity. Nutrients. 2015;7(2):849-64.

39. Georgiev L, Chochkova M, Totseva I, Seizova K, Marinova E, Ivanova G, Ninova M, Najdenski H, Milkova T. Anti-tyrosinase, antioxidant and antimicrobial activities of hydroxycinnamoylamides. Med Chem Res. 2013;22(9):4173-82.

40. Marongiu B, Piras A, Porcedda S, Tuveri E, Sanjust E, Meli M, Sollai F, Zucca $P$, Rescigno A. Supercritical $\mathrm{CO}_{2}$ extract of Cinnamomum zeylanicum: chemical characterization and antityrosinase activity. J Agric Food Chem. 2007;55(24):10022-7.

41. Rescigno A, Casañola-Martin GM, Sanjust E, Zucca P, Marrero-Ponce Y. Vanilloid derivatives as tyrosinase inhibitors driven by virtual screeningbased QSAR models. Drug Test Anal. 2011;3(3):176-81.

42. Kerner von Marilaun A, von Hansen A. Pflanzenleben. Erster Band: Der Bau und die lebendigen Eigenschaften der Pflanzen. (Zellenlehre und Biologie der Ernährung). Leipzig, Germany: Bibliographisches Institut; 1913.

\section{Submit your next manuscript to BioMed Central and take full advantage of:}

- Convenient online submission

- Thorough peer review

- No space constraints or color figure charges

- Immediate publication on acceptance

- Inclusion in PubMed, CAS, Scopus and Google Scholar

- Research which is freely available for redistribution

Submit your manuscript at

www.biomedcentral.com/submit

C BioMed Central 